\title{
Critical Literacy Practices in the EFL Context and the English Language Proficiency: Further Exploration
}

\author{
Mei-yun $\mathrm{Ko}^{1}$ \\ ${ }^{1}$ Department of Applied Foreign Languages, National Formosa University, Taiwan \\ Correspondence: Mei-yun Ko, Department of Applied Foreign Languages, National Formosa University, 64 \\ Wun-hua Rd., Huwei, Yunlin, Taiwan. Tel: 886-5-631-5828. E-mail: mko@nfu.edu.tw
}

Received: August 15, 2013 Accepted: September 7, 2013 Online Published: October 10, 2013

doi:10.5539/elt.v6n11p17 URL: http://dx.doi.org/10.5539/elt.v6n11p17

\begin{abstract}
This paper reports a follow-up study that explored the relationship between EFL learners' critical literacy practices and the English language proficiency. It investigated four focal EFL learners' critical literacy practices in their dialogic interaction and also analyzed 39 students' views on their critical literacy learning. The four focal students' discussion on a gender-related local news article was analyzed based on the concept of critical discourse analysis; the students' views on critical literacy learning were analyzed both qualitatively and quantitatively. The findings showed that despite the difference in their English proficiency, the four focal students all demonstrated critical literacy in varying degrees as shown in its previous study, and that critical consciousness of gender and class are raised through dialogic interaction. This study thus corroborates the previous one that English proficiency does not hinder EFL learner's critical literacy practices. Besides, this study had an additional finding; that is, English proficiency levels do affect EFL learners' views on critical literacy learning. Therefore, a critical literacy-based class would be more acceptable to students whose English proficiency is high.
\end{abstract}

Keywords: critical literacy, language proficiency, group discussion, EFL

\section{Introduction}

Critical literacy has gained much importance in literacy education in the western countries for the past few decades (Behrman; 2006; Ko \& Wang, 2009). It has replaced the narrow skills-based model of learning to read and write, and becomes increasingly important nowadays as students interact with much more information sources in the net age than decades ago. As Janks (2012) pointed out.

In an age where the production of meaning is being democratised by Web 2, social networking sites and portable connectivity, powerful discourses continue to speak us and to speak through us. We often become unconscious agents of their distribution. At the same time, these new media have been used for disseminating counter discourses, for mobilising opposition, for questioning and destabilising power. This is the context within which we need to consider the role of critical literacy in education. (p. 150)

Therefore, to be literate in the contemporary society requires not merely the ability to read and write but a critical mind to see through the assumptions or positions hidden in the text (McLaughin \& DeVoogd, 2004).

In the field of teaching English to speakers of other languages (TESOL), some scholars (Crookes \& Lehner, 1998; Norton \& Toohey, 2004; Pennycook, 1999) also advocate critical literacy pedagogy where teachers do not just teach students basic language skills or train their communicative ability, but also need to develop critical consciousness in students whereby they can question rather than passively accept the information they encounter. Though there has recently been a number of studies concerning critical literacy in TESOL, most of them occurred in the English as a second language setting, and very few have been reported in the English as a foreign language (EFL) context (Ko \& Wang, 2009; Ko, 2013b). One of the reasons for this phenomenon is that critical literacy aimed at developing students to question and challenge taken-for-granted beliefs or dominant practices has been considered culturally inappropriate for the East Asian contexts. Another reason is that many EFL teachers assume that students' limitations in English will preclude their engagement with complex social and moral issues (Ko \& Wang, 2013). For the latter reason, the researcher with her colleague has conducted a study that explored EFL learners' critical literacy practices in relation to their English language proficiency, and the 
results were published in The Asia-Pacific Education Researcher in 2013, titled "EFL learners' critical literacy practices: A case study of four college students in Taiwan" (Ko \& Wang, 2013).

In that study, we explored the critical literacy practices of four EFL learners who had varying English language proficiency levels and had participated in a critical literacy-based reading class. We analyzed their reflective essays and their perceptions of critical literacy, and found that despite the difference in their respective English proficiency, the four students all demonstrated a certain degree of critical literacy and all recognized the importance of critical literacy. However, that study had its limitation in that it only analyzed one piece of reflective essay of each, and thus was not convincing enough. To provide further evidence that EFL students' critical literacy could be developed at any English proficiency level, the present study not only continued to focus on these four EFL learners' critical practice in another situation, that is, by analyzing their group discussion on a local news story, but also further investigated the responses of all of the students to a questionnaire that concerns their critical literacy learning experience in class.

The research questions that the study attempted to address are:

1) Did the four focal EFL learners show critical consciousness in their discussion as they had had in their reflective essays in the previous study? What discourses did they articulate in the discussion?

2) Did the English language proficiency level affect the EFL learners' critical literacy practices? Did it affect their views to critical literacy learning experience?

It is hoped that the results of this follow-up study would provide more insights on the relationship between English proficiency and critical literacy practices in the EFL context, thus filling the educational gap in traditional foreign language teaching where a skill-based method is often the mainstream.

\section{Methods}

\subsection{Setting and Participants}

As a follow-up study, the participants of this study were the same four participants as in Ko and Wang's (2013): Pei-yun, Dan-ni, Jin-chie, and Min-han, who were selected from a critical literacy-based reading class based on their English proficiency level and engagement in class (for a detailed selection procedure, please see Ko and Wang's study, 2013a). Their basic information was presented as in Table 1.

Table 1. A profile of the four participants

\begin{tabular}{llllll}
\hline $\begin{array}{l}\text { Participants' } \\
\text { Pseudonym }\end{array}$ & Gender & Age & $\begin{array}{l}\text { Learning English } \\
\text { History (years) }\end{array}$ & English Proficiency & $\begin{array}{l}\text { Engagement } \\
\text { in Class }\end{array}$ \\
\hline Jin-chie & male & 20 & 10 & advanced & high \\
Pei-yun & female & 21 & 11 & high intermediate & high \\
Dan-ni & female & 21 & 10 & intermediate & average \\
Min-han & male & 21 & 14 & low intermediate & average \\
\hline
\end{tabular}

To further explore these four focal students' development in critical literacy, this study invited them to discuss a local news story together at the end of the semester, and also asked all the other students who enrolled in the same class as the four focal students to answer a questionnaire on their critical literacy learning experience, i.e., the critical literacy-based reading course.

This course, English Reading, was offered to English major students by the Department of Applied Foreign Languages in a college in Taiwan. It was aimed at increasing students' reading comprehension and enhancing their critical literacy. Students met two hours a week for 18 weeks. The two-hour lesson usually started with the teacher's explanation of the text or group presentation of the vocabulary/summary of the text in the first hour, and then small group discussion and whole class sharing/discussion in the second hour. The latter two activities were how a critical stance toward reading was mostly emphasized (for a detailed account of the critical teaching, see Ko, 2013).

\subsection{Data Collections and Analysis Procedure}

Data were collected from the group discussion of the four focal students, an individual interview, and a Likert-scale questionnaire. The four focal students were invited to get together to discuss a local news story, "Female Applicant Wins Claim," after the course ended. It was a story reported in the Taipei Times, an English-language newspaper in Taiwan. The news was about a female university presidency candidate, who filed 
a lawsuit against the Ministry of Education because in an interview for the position, the Ministry's screening committee asked her whether she thought that being "a female candidate would be in an unfavourable position to raise money?" So in her opinion the selection process for university presidency was discriminatory against women. The news story was selected because the news event was local, and the issue was relevant to the topic of gender bias that had been a discussion topic in class. The four students were asked to read the news story ahead before the group discussion. The researcher did not involve herself in the discussion activity because she wanted to learn how they would respond to the news story critically without any intervention, just as they had done in the small group discussion in class. The discussion lasted around 30 minutes. It was audio-taped and transcribed verbatim. Then the researcher carefully read through the transcripts, identified the discourses they employed in the discussion and then interpreted these discourses as the way she had done in the previous study (Ko \& Wang, 2013).

After the four focal students finished their group discussion, the researcher conducted an individual interview with them to know their feelings about the critical literacy-based reading course they had taken. Each interview lasted about 15-20 minutes. All the interviews were conducted in Chinese, and they were audio-taped and transcribed.

The questionnaire was administered at the end of the course to all the students who had taken this reading class, including the four focal students. It consisted of twenty-four statements and one closed-end question. The statements aimed to elicit the students' thoughts and feelings about the critical literacy-based instruction, including instructional materials and classroom activities, self-conceived critical development in the course, reading beliefs, and their beliefs in taking a critical literacy approach to reading in English. The students responded to the 24 statements on a scale of 1 to 5 , with 1 signifying that they "strongly disagree" with the statement, and 5 meaning that they "strongly agree" with the statement. The close-ended question in the questionnaire asked students to estimate their English proficiency level by circling one among the four English proficiency categories - advanced, high-intermediate, intermediate and low-intermediate. The questionnaire was formulated both in English and in Chinese in an effort to avoid possible failure to understand the statements. The students' responses to the questionnaire were analyzed quantitatively. Descriptive statistics were performed using SPSS 16.0. Frequencies, percentages, and means were reported and analyzed.

\section{Analysis and Results}

\subsection{Discussion on the News Story "Female Applicant Wins Claim"}

In this thirty-minute group discussion, the four focal students discussed a local news story, "Female Applicant Wins Claim," which they were assigned to read before the discussion. Jin-chie was the moderator of the discussion and he led the entire discussion in English. Jin-chie was directive and dominated most of the floor because of his fluency in English. Pei-yun also used English in the discussion whereas Dan-ni sometimes used Mandarin Chinese to express her ideas. But Min-han used Mandarin Chinese throughout the entire discussion.

Jin-chie began the discussion with a short summary of the news story. The summary runs as follows: a female university presidency candidate, who was also vice president of a national university, filed a lawsuit against the Ministry of Education because in her interview for the position, one of the screening committee assigned by the Ministry of Education put to her the question: Whether or not would a female candidate be in a disadvantageous position for raising money? This question irritated her because she thought such a question raised in the selection process for university presidency was flagrantly discriminatory against women. After she failed to get the position, she filed a lawsuit against the Ministry of Education because of this sexually discriminatory question and she eventually won the lawsuit. After the brief summary, Jin-chie started posing questions about this news story. Their discussion centred around two topics: the lawsuit and the Law of Gender Equality in Employment.

In the following analysis, I focus on the discourses they employed to make sense of the topics in question in relation to society. In other words, the focus of the analysis was the dialectic relationship between discourse and society (Fairclough, 1992; Gee, 1999).

\subsubsection{The Lawsuit}

Jin-chie began the discussion with an inquiry about the other participants' opinion about this lawsuit. They all thought the question that doubted female's ability to raise funds was obviously sexist. Pei-yun further penetrated into the political dimensions of the sexually discriminatory question; that is, she claimed the question was damaging and caused the female applicant's interest to be at stake. She then pointed out the intention of that particular committee member when Jin-chie posed such a question (Excerpt 1). 


\section{Excerpt 1}

Jin-chie: How is your general impression toward this article?

Pei-yun: I think the guy who asked this question, "The female candidate would be in an unfavorable position to raise money?" The guy who asked this question to Chen Chin-lian, I think he... (Note 1)

Jin-chie: What is the name for the guy?

Pei-yun: Chang Tsung-jen. I think he himself has sexual discrimination because he was asking this kind of question to a female, which indicates that I do not want her to be the president of the university.

Jin-chie: Do you mean Chang Tsung-jen obviously shows his attitude that he doesn't...

Pei-yun: He doesn't like her, and did not want her to be the president of the university.

Then Jin-chie posed a question: Would you file a suit against the MOE (Ministry of Education) if such a thing happened to you? In response to this question, Dan-ni articulated a discourse of lawsuit commonly held by most lower-class Taiwanese; i.e., a lawsuit costs a huge amount of money and if you sue powerful people, the chance of your winning the suit is extremely small. Therefore, she would not file suit in this case (Excerpt 2).

\section{Excerpt 2}

Jin-chie: OK, I think Pei-yun share a good point of view, but I would like to ask Dan-ni. If you were the person, will you be brave enough to file a suit against MOE, Ministry of Education? Which you...You are like a small organization or small part and MOE is kind of a huge and represent the authority. Will you be brave or courageous enough to sue or to file a suit against MOE? Dan-ni, would you mind sharing your opinion?

Dan-ni: If I were her, I won’t sue MOE.

Jin-chie: Why would you not sue?

Dan-ni: Because it will cost a lot of money and...

Min-han: But if you won the suit, you could make the other party pay the expenses (Note 2).

Dan-ni: The chance to win is...

Jin-chie: The likelihood is not likely.

Despite being assured that the money would not be a problem in that she were vice president of a national university, Dan-ni would still not file suit and continued to elaborate a discourse of lawsuit based on her usual skepticism, which deemed a favorable verdict to be hopeless because of the judge's subjective arbitration (Excerpt3).

\section{Excerpt 3}

Jin-chie: Don't forget you are the vice president of National University. You have certain degree or income, paid income, your financial condition is secure, so OK if you have enough money, would you sue MOE? You don't have problems with your finance.

Dan-ni: I will consider about it. I am not sure whether to file a suit...

Jin-chie: What is your consideration?

Dan-ni: The law and the cost and the extreme cost. It is right for everybody. I don't know because the result is winning or not is judged by the judge.

Jin-chie: Judges, right?

Dan-ni: Judges, and we don't know how serious a sentence is. That is to say, I am not sure I can win the lawsuit just based on the so-called sexist statement. Besides, we don't know whether this statement is really discriminatory or not. Things like that are very subjective, you know.

Unlike Dan-ni, Pei-yun said she would file a suit if she were the female applicant because, being the vice president of a national university, she had the money needed for the lawsuit and the chance of winning was also very high. In contrast to Dan-ni's discourse of lawsuit held by the lower class people, Pei-yun articulated a discourse of lawsuit that is understandable to upper-class Taiwanese, i.e., social elites such as doctors, lawmakers, entrepreneurs, and university professors. However, when Jin-chie directed the discussion to the social pressure on females when they are filing suit, Pei-yun articulated a tolerance discourse to explain why she would consider 
dropping the suit. The idea behind the tolerance discourse is that females will sacrifice their small, temporary interest for the bigger and long-term one, which can explain many females' tolerant and conciliatory behavior confronting discriminations in a patriarchic society in which unequal power relations exist (Excerpt 4).

\section{Excerpt 4}

Jin-chie: Would you file a suit if you were her? Would you?

Pei-yun: Yes...

Jin-chie: Why is that?

Pei-yun: Because I have money and I think the chance to win is much higher.

Jin-chie: I think we can view from two perspectives, one: whether you are rich enough or not, or whether you have enough money for a suit or not...Like to employ a lawyer to defend for you. But another thing: don't you really pay attention to how society will view this? Will give you...Just will you put a society pressure into consideration in deciding to sue or not... How about the pressure from society? You think will you put it into consideration for whether to sue or not?

Pei-yun: Yes!

Jin-chie: So what will make you not to sue, not to file a suit? What kind of pressure?

Pei-yun: Now we are talking about pressure. For example, your parents, maybe if you are just a small employee, you want to sue your boss. And your parents may say that "That's so stupid. You can just keep quiet. And you need money, the salary from your boss."

Jin-chie: Tolerate.

Pei-yun: You just tolerate it for a while and everything will be fine.

Jin-chie also posed the same question to Min-han, but from a different angle; that is, would he support his wife in filing suit against the MOE if she faced a similar situation? Min-han said he would support his wife in her lawsuit against powerful organizations such as the MOE. Even if his wife would withdraw from such a legal action, he would nonetheless insist that she file suit. Dan-ni further challenged Min-han with another difficulty for filing suit, i.e., the money problem. Despite that, Min-han remained unmoved in his decision to urge his wife to file suit because of his firm conviction that one should fight for one's own rights. Therefore, he said he would even borrow the money for filing the suit. Min-han was obviously articulating a principle-based discourse which holds the idea that people should adhere to certain principles and there is a clear-cut demarcation between what is wrong and what is right. The principle Min-han adhered to was that one must fight for one's own right in any circumstances (Excerpt 5).

Excerpt 5

Jin-chie: Min-han, if one day, ok, we hope this will not happen in the future. Your wife faces the situation, and will you support her to file a suit? And why?

Min-han: I will. I will fight for my rights.

Jin-chie: But if she says no, she doesn't want to file a suit?

Min-han: You said my wife were vice president of national Taiwan University of science and technology ...

Jin-chie: Yeah, Min-han, if your wife thinks it is not necessary to sue MOE, will you still persuade her to continue to file?

Min-han: Sure, because she must fight for her rights.

Jin-chie: But she thinks not to do so...she doesn't think it is necessary.

Min-han: why it is not necessary. If men want to sell skin-care or cosmetic products, can we reject them because we think they can't convince female buyers? This is not right. This is you guys stereotyping concept...

Dan-ni: What if you have financial problem, will you?

Jin-chie: Yeah, I think Dan-ni raises a good question. Today you answer this because you have steady income, but what if your financial situation is not so good or Ok...it is very hard to avoid the fee during the process. Will you still do? My question is if your financial condition is not sufficient for you, it will affect your decision to sue or not? 
Min-han: Yes. I will still sue ....

Jin-chie: You will still sue.

Dan-ni: You will borrow the money from...

Min-han: Yes. I will borrow money because one must fight for his rights, and if you think you are right, you have to stick to it...

\subsubsection{Sexual Discriminations in Workplaces \& the Gender Equality in Employment Law}

Immediately following their discussion concerning the lawsuit, Jin-chie directed the discussion to the Gender Equality in Employment Law, which the female applicant, vice president of National Taiwan University of Science and Technology, accused the screening committee of having violated. In discussing why there was such a law in Taiwan, Dan-ni and Pei-yun pointed out there were instances of sexual discrimination against women in workplaces and the law was made to protect women (Excerpt 6).

\section{Excerpt 6}

Jin-chie: Let's look at here. The Gender Equality in Employment Law. The Gender Equality in Employment Law (Note 3). Anybody shares something, your understanding about this law? What this law may be about?

Dan-ni: Is it about the equality between women and men?

Pei-yun: It is a law to protect women.

Jin-chie: So The Gender Equality in Employment Law is constituted to protect women?

Pei-yun: In working area.

To invite more discussion on the gender equality issue, Jin-chie posed a question: "Does it mean that men are superior to women in working ability and the law is therefore set up to protect them?" This gendered discourse immediately invoked strong reactions from Dan-ni and Pei-yun. However, when Jin-chie raised the possibility of a utopian vision in which there is no gender discrimination in society, both Dan-ni and Pei-yun became reserved, knowing that the concept of gender inequality is too deeply-rooted in Taiwan society to be totally eradicated and women are frequently unfairly treated in workplaces because of some prejudiced ideas about them. Therefore, Dan-ni pointed out that The Gender Equality in Employment Law was made to protect the rights and the welfare of women in workplaces (Excerpt 7).

\section{Excerpt 7}

Jin-chie: In working area, right? So does it imply that women are inferior to men, so we have to have a law to protect women? Does it imply that? Is my statement true?

Dan-ni: Because in the past, women in the workplace were often looked down. So they made this law to protect women's rights in work place.

Jin-chie: So does that mean women's working ability are not as good as men's?

Pei-yun: It doesn't mean that.

Dan-ni: It is about welfare.

Jin-chie: In the future, Taiwan progresses and becomes a really no-gender-discrimination country. Can we delete this rule, this regulation?

Dan-ni: We still have...

Pei-yun: But it is impossible for Taiwan to be no gender discrimination.

To explain this oppressive social phenomenon, Dan-ni produced a cynical discourse based on her previous scepticism saying that gender discrimination would always exist regardless of what society you lived in whereas Pei-yun gave a constructivist discourse saying that gender discrimination was socially and culturally constructed. If such discrimination is learned, i.e., socio-culturally constructed, the only solution to this problem is through education, i.e., to unlearn it through de-socializing thinking (Shor, 1992). Pei-yun understood that it was very difficult for people to think outside their naturalized, therefore comfortable, modes of thought; therefore, she helplessly admitted that it is very hard for people to change or to change people when Jin-chie raised a possible solution to this problem through education (Excerpt 8). 


\section{Excerpt 8}

Jin-chie: Do you think is it possible for any country to be gender-discrimination free?

Dan-ni: No matter it is any country, there is still gender discrimination, always.

Jin-chie: So how should we solve this problem? From education or from....in what means? So in what means can we solve or try to, just to...

Pei-yun: It's hard.

Jin-chie: Yeah, you think it is hard...

Pei-yun: It's a cultural thing or about a society...how can you change it?

To conclude, the critical development of these four focal students is seen in two aspects of critical literacy: consciousness raising and action taking. In this focal group reading discussion, critical consciousness of gender and class are raised through dialogic interaction. For instance, Pei-yun was able to perceive the discriminatory exclusion behind a statement that doubted a female's ability to raise funds. Dan-ni was also aware of class distinction, i.e., lower-class people's mentality vs. upper-class people's through her lived experiences when she articulated her discourse of lawsuit. Critical consciousness of the discriminatory exclusion resulting from gender and class will certainly empower students to rename the world (Freire, 1974) by articulating a counter-discourse. One of the main goals of critical literacy lies in its effort to bring about social transformation for an egalitarian society; therefore, critical literacy practice will not be complete until critical consciousness is translated into emancipatory action. The great part of this focal group reading discussion was devoted to the question of whether or not they would file suit in such a discriminatory situation. Except for Dan-ni, whose cynicism seemed to override her critical consciousness, all the other focal students realized the importance of action taking. This is most obvious in Min-han's discourse, which insisted on fighting for one's own rights. Their discussion of The Gender Equality in Employment Law has also demonstrated the importance of action-taking in protecting the welfare and the rights of working women. In short, this focal group discussion on "Female Applicant Wins Claim" demonstrated the four focal students' critical development in varying degrees.

\subsection{Analysis of Critical Literacy Learning Experience}

\subsubsection{The Interviews}

The analysis of the interview data showed that the four focal students' English proficiency along with their past English learning experience influenced their attitudes toward the critical literacy-based course. The advanced students, Jin-chie and Pei-yun, held a more favourable opinion of their critical literacy learning experience than the less advanced students, Dan-ni, and Min-han. The following respectively described and analyzed their views to this course, including their self-perceived critical development, the critical discussion activities, and reading materials:

\section{(1) Jin-chie}

Jin-chie felt this course had influenced his way of reading in English. He had great interest in the critical literacy approach to reading, enjoying discovering how the authors influenced or maneuvered the readers to take up certain views by positioning them in the text. Without any experience in critical reading in the past, this new experience was both interesting and meaningful to him. He said,

I never read in this way. Now in reading, I will pay attention to what are the values that the authors want their readers to believe. I will notice whose voice is eliminated and whose voice is overemphasized in the text. (Interview with Jin-chie)

$\mathrm{He}$ appreciated the critical discussion activities. This experience enhanced his confidence not only as a competent reader but also as a confident speaker in English. He was confident when sharing his opinions at the front. In the small group discussion, he often took the lead, helping write down the main points of their group discussions for the wrapper (Note 4) even though he was not the wrapper of the week. "I like the small group discussion the most because we could exchange each other's opinions, obtain some ideas that did not come to me, and understand others' viewpoints - how others look at things from a different angle."

(2) Pei-yun

Pei-yun, the other advanced student, also had a positive view of this course. The course was very helpful to her and she felt she gained a sense of achievement from this course because she found she was able to discuss critically with other classmates about the social issues. She remarked:

I have already come to the peak of English proficiency, having sufficient vocabulary to talk and read English 
without difficulty. I can get high scores in all kind of English tests. So critical thinking is useful to me. I can use my English to discuss social problems more deeply. (Interview with Pei-yun)

Pei-yun was more enthusiastic than others to learn to read from a critical perspective. She said, "I even go online to search supplemental materials related to critical reading to learn more about it." She was the only one among these four participants who had had experience of critical reading prior to this course. Therefore, she was more ready than the others to develop her critical literacy.

Pei-yun also liked the group discussion activity. She said, "We can share and hear others' opinions." However, unlike Jin-chie, she believed they should discuss entirely in English and earnestly wished the course instructor had asked them to do so. She complained, "If you were the only one that talked in English, the others would think you were showing off. So I think the teacher should set a rule - no Chinese in group discussion." She continued, "I love the literature circle (Note 5) idea that everyone has a role to play in the discussion group, but unfortunately, many of us said something irreverent; therefore sometimes I felt I could not learn much from the discussion." Pei-yun seemed to consider discussions that had strayed from the text to be off-topic and would like every student to have played their role seriously in small group discussion.

(3) Dan-ni

Like the advanced students, Dan-ni liked the critical discussion activities. "The discussions helped me with more ideas or opinions. I can express my ideas more completely in writing," she remarked. However, she was not so interested in a critical approach to reading as Jin-chie and Pei-yun, but she found that learning to read in this way expanded both her thinking capacity and language knowledge. She revealed, "To read an article critically, I read the article from the opposite perspective. This experience is just like I'm reading another article. So I feel I gained more knowledge by knowing the unsaid meaning of the article." Therefore, she had attempted to think from different perspectives, to question what was read and not to believe everything authors wrote. However, she was afraid she might oppose the author's ideas only for the sake of opposition. She said,

But sometimes I was afraid I might distort the author's meaning when I tried to think in the opposite direction. I was afraid I might overdo it. I read critically after this course, especially watching TV critically. For example, for the same event, I find the reporters could report quite differently because of their different ideological positions. (Interview with Dan-ni)

In fact, "being critically literate is not a matter of changing or denying a position but a matter of considering multiple meanings and constructions of social identities and discourses" (Janks, 1993; Morgan, 1997, cited in Alford, 2001, p. 135).

Though Dan-ni acknowledged the benefit of critical literacy, she believed the most important aspect in reading in English was to be able to comprehend the text without difficulty. As a slow reader, she was overwhelmed with the length and wide vocabulary of the reading articles in class and felt somewhat discouraged when reading them.

\section{(4) Min-han}

Min-han's attitude toward the critical literacy-based reading course was negative in the beginning but turned positive in the end. It was because he had been used to the banking education. His past teachers had a decisive impact on his learning and reading in English, who taught students how to decode the text effectively and to identify the man idea quickly so that they could receive high scores on the standardized comprehension test in the college entrance exam. He confessed:

My past teachers, the teachers in the cram school, used the 'banking pedagogy.' They poured everything onto you. They taught me all the test skills needed for the college entrance exam. I found it was most efficient and helpful. I appreciated that kind of teaching. (Interview with Min-han)

However, he gradually found it interesting to hear others' opinions and share his own as the course went on. He said,

I like the whole class sharing activity. I was amazed at the classmates'great ideas. Everyone thought differently... When I played the role of the wrapper, though quite nervous, I knew I was being trained to express myself in English in public. In the future when we enter into the workforce, we may need to make a presentation to our boss, so I liked the experience of group presentation and whole class sharing where we need to report in English to the whole class. (Interview with Min-han)

Though sharing ideas in English was challenging for him, Min-han liked the whole class sharing and group presentation activities, where he enjoyed listening to others' ideas. Like Dan-ni, the complaint he had about was 
the reading materials they used for this course. "The reading articles were too long. I felt it was tedious reading them." He suggested that the teacher distribute to them a shorter reading article instead and give them a short time to read it in class, prior to the small group discussion and whole class sharing activities. He further emphasized, "The reading articles had better cover all different areas such as biology, history, geography, and so on." The reading materials Min-han expected to use in the reading course were similar to those that appeared in the reading part of the TOEIC (Test of English for International Communication).

In brief, the four focal students found the discussion in small groups interesting and stimulating, but their views toward the reading materials differed. Jin-chie and Pei-yun viewed the reading materials as interesting and the discussion of the hidden ideologies behind the texts intellectually stimulating and challenging, while Dan-ni and Min-han felt the reading materials were noticeably challenging and the tasks which required them to express themselves in English were apparently difficult.

\subsubsection{The Questionnaire}

The results of the students' responses to the questionnaire showed that 10 students perceived themselves to be at advanced and high-intermediate English proficiency level, and 29 students considered themselves to be at intermediate or low-intermediate level. The former (i.e., the higher-level group) were designated Group 1 and the latter (i.e., the lower-level group) designated Group 2. Table 2 presents the mean values and the standard deviations of the responses to the questionnaire in these two groups and the mean difference between them (Note $6)$.

Table 2. Responses to the questionnaire

\begin{tabular}{|c|c|c|c|c|c|}
\hline \multirow[t]{2}{*}{ Item No./ Statements } & \multicolumn{2}{|c|}{$\begin{array}{l}\text { Group } 1 \\
(\mathrm{~N}=10)\end{array}$} & \multicolumn{2}{|c|}{$\begin{array}{l}\text { Group } 2 \\
(\mathrm{~N}=29)\end{array}$} & \multirow{2}{*}{$\begin{array}{l}\text { Mean } \\
\text { Difference (md) } \\
\text { M1-M2 }\end{array}$} \\
\hline & M1 & SD & M2 & SD & \\
\hline $\begin{array}{l}\text { 1. The reading materials used in this } \\
\text { course are interesting. }\end{array}$ & 4.20 & .632 & 3.52 & .738 & 0.68 \\
\hline $\begin{array}{l}\text { 2. The reading materials match my } \\
\text { English proficiency level. }\end{array}$ & 4.50 & .527 & 3.76 & .577 & 0.74 \\
\hline $\begin{array}{l}\text { 3. The instructor's text explanation is } \\
\text { helpful to my reading comprehension. }\end{array}$ & 4.00 & .816 & 3.52 & .688 & 0.48 \\
\hline $\begin{array}{l}\text { 4. The questions the instructor posed in } \\
\text { class help me read critically. }\end{array}$ & 4.20 & .919 & 3.86 & 693 & 0.34 \\
\hline $\begin{array}{l}\text { 5. The group presentation activity is } \\
\text { helpful to my reading comprehension. }\end{array}$ & 3.00 & 1.414 & 3.21 & .861 & -0.21 \\
\hline $\begin{array}{l}\text { 6. The small group discussion activity } \\
\text { helps me read critically. }\end{array}$ & 3.80 & .632 & 3.62 & .775 & 0.18 \\
\hline $\begin{array}{l}\text { 7. The small group discussion activity } \\
\text { should be conducted in English. }\end{array}$ & 4.20 & .789 & 3.62 & .677 & 0.58 \\
\hline $\begin{array}{l}\text { 8. The whole class sharing activity helps } \\
\text { me read critically. }\end{array}$ & 3.50 & .850 & 3.55 & .736 & -0.05 \\
\hline $\begin{array}{l}\text { 9. The whole class sharing activity should } \\
\text { be conducted in English. }\end{array}$ & 4.60 & .516 & 3.76 & .739 & 0.84 \\
\hline $\begin{array}{l}\text { 10. The whole class discussion helps me } \\
\text { read critically. }\end{array}$ & 3.70 & .949 & 3.66 & .814 & 0.04 \\
\hline $\begin{array}{l}\text { 11. The reflection assignment helps me } \\
\text { read critically. }\end{array}$ & 4.10 & .994 & 3.66 & .670 & 0.44 \\
\hline $\begin{array}{l}\text { 12. I feel I worked hard on the reflection } \\
\text { assignment. }\end{array}$ & 4.50 & .707 & 4.10 & .618 & 0.40 \\
\hline $\begin{array}{l}\text { 13. Overall, this course helps me read } \\
\text { critically. }\end{array}$ & 4.10 & .876 & 3.76 & .511 & 0.34 \\
\hline $\begin{array}{l}\text { 14. This course meets my expectations } \\
\text { for a reading course. }\end{array}$ & 3.80 & .789 & 3.24 & .636 & 0.56 \\
\hline $\begin{array}{l}\text { 15. This course improves my English } \\
\text { reading ability. }\end{array}$ & 3.40 & .516 & 3.28 & .751 & 0.12 \\
\hline 16. This course helps me read beyond the & 4.50 & .527 & 3.59 & .825 & 0.91 \\
\hline
\end{tabular}


surface meaning of texts.

17. This course helps me understand how texts are manipulated for certain purposes.

$4.30 \quad .675$

$.675 \quad 3.45$

$3.45 \quad .827$

0.85

18. This course helps me to connect my

lived experiences to the text when reading.

19. This course helps me consider multiple perspectives when reading.

20. This course helps me to disrupt the taken-for-granted assumptions in the text.

21. This course develops my awareness of how texts influence our thoughts and actions.

22. I like that the teacher takes a critical approach to the English reading course.

23. I think it is important to read critically even in English

$\begin{array}{lllll}4.20 & .919 & 3.79 & .726 & 0.41\end{array}$

$\begin{array}{lllll}4.00 & .667 & 3.52 & .509 & 0.48\end{array}$

$\begin{array}{lllll}3.80 & .789 & 3.52 & .509 & 0.28\end{array}$

$\begin{array}{lllll}3.80 & .919 & 3.59 & .825 & 0.21\end{array}$

$\begin{array}{lllll}3.80 & .789 & 3.48 & .738 & 0.32\end{array}$

24. I will take a critical approach to reading in the future.

$\begin{array}{lllll}4.60 & .699 & 4.03 & .626 & 0.57\end{array}$

$\begin{array}{lllll}3.70 & .949 & 3.59 & .628 & 0.11\end{array}$

Note: $\mathrm{M} 1=$ mean value of Group 1

M2 = mean value of Group 2

$\mathrm{MD}=$ the mean difference between $\mathrm{M} 1$ and M2

As is apparent in Table 2, in most items, the mean values of Group 1 are higher than those of Group 2 except for Item 5 and Item 8. In other words, the students at higher English proficiency level (Group 1) had a more favourable view toward the critical literacy-oriented course and a critical literacy approach to reading than those at lower level (Group2). Only in Item 5 and Item 8 was the mean values of Group 1 slightly lower than that of Group 2 (-0.21 and -0.05), but the difference was extremely small.

Both groups had a positive response to Item 23 , with the mean value more than $4.0(\mathrm{M} 1=4.60 ; \mathrm{M} 2=4.03)$. In other words, most of the students, be they advanced or less advanced, believed that it was important to read critically even the text was in English. This result is consistent with the study with the four focal students discussed above.

The items to which both groups had a negative response, with the mean value less than 3.5 , are Item $5(\mathrm{M} 1=3.00$, $\mathrm{M} 2=3.21)$ and Item 15 ( $\mathrm{M} 1=3.40, \mathrm{M} 2=3.28)$. In other words, the majority of students did not think that the group presentation activity helped with their reading comprehension nor felt that this course helped improve their English reading ability. The group presentation activity was an activity where one group was designated to explain the vocabulary and summarize the main ideas prior to their discussion. Therefore, the negative response means that many students did not think their own explanation of vocabulary or summary was helpful to their comprehension of the text. They preferred the instructor's explanation to their own. Such a result might be attributed to students' better trust in the instructor's knowledge than in their own.

Regarding the negative response that the students did not perceive improvement in reading abilities, it might be related to their conceptions of what is regarded as reading abilities. For most EFL learners, having good English reading ability means they could read fluently, comprehending the text without difficulty. This reading belief was also revealed in Item $14(\mathrm{M} 1=3.80, \mathrm{M} 2=3.24)$, showing that the critical literacy-based reading course did not meet most of the students' expectations for an English reading course. In this course, the teacher spent half of class time on the literal understanding of the text, but the other half of class time focused on a critical literacy approach to reading, which was different from the traditional EFL reading class. This might be the reason why many of them believed the course enhanced their critical reading or thinking (Item 13, M1=4.10, M2=3.76), but not their English reading ability (Item 15, M1=3.40, M2=3.28). It was particularly true for the lower-level students to have this reading belief. For example, Min-han and Dan-ni, whom we discussed earlier, both expected that a reading course was to teach them how to comprehend the text.

In addition to Item 14 that showed very different response between these two groups ( $\mathrm{md}=0.56)$, Item 1, 2, 7, 9 , 16 , and 17 all had the mean difference more than 0.50 . The difference in Item $16(\mathrm{md}=0.91)$ and Item 17 
$(m d=0.85)$ suggests that the critical instruction seemed to be far more helpful to advanced students than less advanced students while developing their critical consciousness like " to read beyond the surface meaning of texts" and "to see how texts are manipulated for certain purposes." The difference in Item $1(\mathrm{md}=0.68)$ and Item $2(\mathrm{md}=0.74)$ suggests that the reading materials were interesting to the higher-level students but appeared difficult to the lower-level students, which was again congruent with the study with the four focal students. The different response to Item $9(\mathrm{md}=0.84)$ and Item $7(\mathrm{md}=0.58)$ indicate that the advanced students preferred to discuss in the target language English rather than in their native language Chinese, but for the less advanced students, to discuss in English in a critical literacy-based reading class seemed difficult and challenging.

To sum up, the results of the questionnaire revealed that the students perceiving themselves to have better English proficiency held more favourable views toward the critical literacy-oriented instruction and a critical approach to reading. Therefore, a critical literacy-based reading class would be more acceptable to students whose English proficiency is high.

\section{Discussion and Conclusion}

The finding of this study corroborates its previous study (Ko \& Wang, 2013) that the four focal students, though at very different English proficiency levels, all demonstrated a certain degree of critical literacy in their dialogic interaction as they had had in their reflective essays. In their group discussion, they were all able to discuss the news story from a critical perspective and thus achieved critical consciousness to some extent: Jin-chie, who acted as a moderator of the discussion, demonstrated his ability to pose critical questions; Pei-yun was also able to perceive the political and social implications of the sexist discourse; Min-han articulated a principle-based discourse to the issue of the lawsuit, adhering to the principle that everyone had to fight for their own rights in any situations. Dan-ni similarly attempted to be critical by holding a distrusting stance to filing suit, thus producing a skeptical discourse. Therefore, EFL learners' English proficiency level did not hinder their critical literacy development.

However, the English language proficiency level affected EFL learners' perception of critical literacy learning. The advanced students showed greater interest in the critical literacy approach to reading than the less advanced; they found the reading materials intriguing and preferred the critical discussion in English, while the less advanced students felt the reading articles difficult and tedious and the discussion requiring them to express in English challenging.

Ideal reading materials for a critical literacy-based classroom should be related to students' lives and experiences (Shor, 1992), but they should attend to the levels of students' language proficiency. In the EFL context, locally-published English-language newspaper articles that have immediate relevance to students' lives could be a good choice. Materials which are more related to students' lives around them can more easily lead to a deep exploration of the problems that brings about the fruit of critical literacy. If possible, start with obviously biased or ideologically loaded texts that easily lead students to adopt a critical stance to reading, and then progress to more subtle ones.

Regarding the use of the target language in a critical literacy classroom, it is not encouraged by most critical literacy educators. They emphasize that the teacher encourage students to use their own language, but in EFL contexts, it seems a moot question to encourage students to use the first language, especially for the high proficient students who have a strong desire for communication in English. Based on the result of this study, we suggest that both the target language and the first language could be used at the same time to meet the dual purpose of language development and critical literacy. Students could be encouraged to use their first language in small group discussions but the target language in whole class discussion.

Therefore, this study concluded that EFL learners' English proficiency did not influence their development of critical literacy but their views toward critical literacy-based instruction. Critical literacy could be implemented in the EFL context even though the students' English proficiency was still limited, but special attention should be paid to the selection of the reading materials and the use of the target and first language.

\section{References}

Alford, J. (2001). Critical literacy and second language learning in the mainstream classroom: An elusive nexus? Retrieved from http://eprints.qut.edu.au/1015/1/alford_book_BD39DD8.pdf

Behrman, H. (2006). Teaching about power, language, and text: A review of classroom practices that support critical literacy. Journal of Adolescent and Adult Literacy, 49, 490-498. http://dx.doi.org/10.1598/JAAL.49.6.4

Crookes, G., \& Lehner, A. (1998). Aspects of process in an ESL critical pedagogy teacher education course. 
TESOL Quarterly, 32, 319-328.

Daniels, H. (1994). Literature circles: Voice and choice in the student-centered classroom. Portsmouth, NH: Heinemann.

Fairclough, N. (Ed.) (1992). Critical Language Awareness. New York: Longman.

Freire, P. (1974). Education for critical consciousness. London: Continuum.

Gee, J. P. (1999). An introduction to discourse analysis: Theory and Method. London: Routledge.

Janks, H. (2012). The importance of critical literacy. English Teaching: Practice and Critique, 11(1), 150-163. Retrieved from http://edlinked.soe.waikato.ac.nz/research/journal/view.php?article=true\&id=788\&p=1

Ko, M. (2013a). A case study of an EFL teacher's critical literacy teaching in a reading class in Taiwan. Language Teaching Research, 17, 91-108. http://dx.doi.org/10.1177/1362168812457537

Ko, M. (2013b). A critical discourse analysis of EFL learners' post-reading reflections in a critical literacy-based class. English Linguistics Research, 2(2). http://dx.doi.org/10.5430/elr.v2n2p1

Ko, M., \& Wang, T. F. (2009). Introducing critical literacy to EFL teaching: Three Taiwanese college teachers' conceptualization. Asian EFL Journal, 11(1), 174-191.

Ko, M., \& Wang, T. F. (2013). EFL learners' critical literacy practices: A case study of four college students in Taiwan. The Asia-pacific Education Researcher, 17, 221-229. http://dx.doi.org/10.1007/s40299-012-0013-5

McLaughlin, M., \& DeVoogd, G. (2004). Critical literacy: Enhancing students' comprehension of text. New York: Scholastic Inc.

Norton, B., \& Toohey, K. (2004). Critical pedagogies and language learning. Cambridge University Press. http://dx.doi.org/10.1017/CBO9781139524834

Pennycook, A. (1999). Introduction: Critical approaches to TESOL. TESOL Quarterly, 33, 329-348. http://dx.doi.org/10.2307/3587668

Shor, I. (1992). Empowering education: Critical teaching for social change. London: University of Chicago Press.

\section{Notes}

Note 1 . The symbol ... means a continuous tone.

Note 2. Italicized texts: The words spoken in Chinese were italicized in all the excerpts in this section.

Note 3. Jin-chie repeated the words "The gender Equality in Employment Law" in Chinese.

Note 4. A wrapper was responsible for sharing in front of the class what their group had discussed in the small group.

Note 5. For the small group discussion, the course teacher used a device similar to "literature circle" (Daniels, 1994) by which each group member in turn took the role of director, connector, challenger, and wrapper.

Note 6 . The independent t-test was not employed here because the sample size of each group was small and unequal, $\mathrm{N} 1=10, \mathrm{~N} 2=29$. Therefore, only the mean difference between these two groups was given and analyzed.

\section{Copyrights}

Copyright for this article is retained by the author(s), with first publication rights granted to the journal.

This is an open-access article distributed under the terms and conditions of the Creative Commons Attribution license (http://creativecommons.org/licenses/by/3.0/). 